\title{
PCR assay a new approach for detection of enterotoxins
}

\author{
K. A. Khater * and S. A. Abdella \\ 1 Dairy Department, Faculty of Agriculture, Al Azhar University, Cairo, Egypt \\ *Corresponding author E-mail: khaterkhater.5@azhar.edu.eg (K. Khater).
}

\begin{abstract}
B. cereus group is considered as a potential problem, since it can contaminate many dairy products. In this study, three primer sets were selected to simultaneously detect two different species of the B. cereus group by using triple - primer PCR. The triple-primer PCR in this study were synthesized using the CER, CES and groEL genes for the detection of emetic toxin producing strains and another specific primer for the detection of diarrheal toxin (groEL gene only). Results indicated that all the diarrheal enterotoxin producing B. cereus strains showed a presence of groEL gene, while CER and CES genes were completely absent. Out of the six $B$. cereus strains tested for the production of diarrheal and emetic enterotoxins by using triple-primer PCR technique, three diarrheal enterotoxin producing strains were only detected. On the other hand, all six $B$. cereus strains had limited ability to produce emetic toxin. All diarrheal enterotoxin producing B. mycoides strains showed presence of groEL gene, but CER and CES genes were not detected in any of the B. mycoides tested strains. Consequently, four B. mycoides strains were tested for the production of diarrheal and emetic enterotoxins by using triple-primer PCR technique, only two strains showed diarrheal enterotoxin producing strains. In contrary all B. mycoides tested strains had limited ability to produce emetic toxin.
\end{abstract}

Keywords: Aerobic spore forming bacteria; Milk products; B. cereus group; Enterotoxin producing.

\section{INTRODUCTION}

The genus Bacillus contains 51 species and is divided into three groups based on the morphology of spores and sporangia (Groups 1-3). Group 1 is subdivided into 1A and $1 \mathrm{~B}$ based on the cell size and the presence of poly $-\beta$ - hydroxybutyrate in the cytoplasm. The organisms belong to Group 1A (B. cereus group) are; B. cereus, B. anthracis, B. thuringiensis, B. mycoides, B. psuedomycoides and $B$. weihenstephanensis. Enterotoxin production is linked to Bacillus induced disease and a majority members of Group $1 \mathrm{~A}$ produce enterotoxin (Bhunia, 2008).

Bacillus cereus is Gram - positive, rod shaped, spore forming bacterium and a human opportunistic pathogen, which can cause diarrheal and emetic types of food poisoning (Arnsen et al.,2008). B. cereus is commonly found in a wide variety of different foods and environments (Duc et al., 2005; Bartoszewicz et al., 2008).

The enterotoxins that have been associated with diarrheal type food poisoning are hemolysin BL (HBL), nonhemolytic enterotoxin (NHE), cytotoxin K (CytK) and enterotoxin FM (Lund et al., 2000; Sergeev et al., 2005). However, enterotoxins have already been comparatively well characterized at the molecular level (Lund $e t$ al., 2000) and in immunochemical assay (Dietrich et al., 2005).

Additionally, emetic type food poisoning is caused by an emetic toxin (cereulide). This type of food poisoning is small, heat and acid stable circular dodecadepsipeptide with the following stereochemistry: [D-O-Leu-D-AlaL-O-Val-L-Val]. (Ehling-Schulz et al., 2005).

However, since the first case of human food poisoning by Bacillus group was detected, $B$. cereus group has been implicated in various outbreaks worldwide (Stenfors et al., 2008; Bennett et al., 2013).

Moreover, B. cereus group is considered as potential problem since it can contaminate many dairy products in several countries (Sadek et al., 2006; Reyes et al., 2007; Bartoszewicz et al., 2008; Zhou et al., 2010; Mohamed et al., 2016). This group is able to cause two types of syndroms i.e. diarrheal and emetic. Also, B. cereus group is an important spoilage organism to many foods (Tan et al., 1997; Fermanian, 1997).

Traditionally, B. cereus group have been associated with the spoilage of food products, however, recently they have been linked to potential food poisoning issues (Rodriguez-Lozano et al., 2010). 
Recently, several investigators used Triple-primer polymerase chain reaction (PCR) assay to detect diarrheal and emetic toxins producing by $B$. cereus group strains (Zhou et al., 2010; Kim et al., 2013).

Therefore, the aim of the current study was to used a reliable and accuracy method for detection enterotoxic genes by PCR technique in B. cereus group strains.

\section{MATERIALS AND METHODS}

\section{Gel preparation ( $1 \%$ agarose gel)}

Agarose gel 1\% is prepared by adding $1 \mathrm{~g}$. of agarose to $100 \mathrm{ml}$. TBE. The solution was boiled to dissolve the agarose in microware oven for 1-3 min., and cooled down to $45^{\circ} \mathrm{C}$, $3 \mu \mathrm{L}$ of ethidium bromide $(1 \%)$ was added and left for solidification at room temperature.

\section{PCR master mix}

GoTaq Green Master Mix, is a premixed ready-to-use solution containing bacterially drived Taq DNA polymerase, dNTPs, $\mathrm{Mg} \mathrm{Cl}_{2}$ and reaction buffers at optimal concentration for efficient amplification of DNA templates by PCR.

\section{Genomic DNA isolation Kit}

Total genomic DNA was extracted from ten isolates according to manufacture instructions using Zymo Research. Fungal/ Bacterial DNA Mini Prep ${ }^{\mathrm{TM}}$ Kit (catalog No. D6005 ZR CORP, India). The Kits were purchased from Sigma Company, Egypt. PCR primers and annealing temperature used for the detection of emetic and diarrheal toxins:

The three primer sets which used in the present study are illustrated in Table 1.

Table1. PCR primers and annealing temperature for the detection of emetic and diarrheal toxin producing B. cereus group.

\begin{tabular}{llccc}
\hline $\begin{array}{l}\text { Primer } \\
\text { name }\end{array}$ & \multicolumn{1}{c}{ Primer sequence (5'-3') } & AT & $\begin{array}{c}\text { Amplicon } \\
\text { size }(\mathrm{bp})\end{array}$ & Reference \\
\hline $\begin{array}{l}\text { CER F-5 } \\
\text { CER R-5 }\end{array}$ & $\begin{array}{l}\text { CAAGTCAAGATAAGAGGCTTC } \\
\text { AAAGCTCTTGCCAAATAACC }\end{array}$ & $54^{\circ} \mathrm{C}$ & 370 & Kim et al. (2013). \\
\hline $\begin{array}{l}\text { CES F-10 } \\
\text { CES R-10 }\end{array}$ & $\begin{array}{l}\text { GCATTTCGTGAAGCAGAGGT } \\
\text { CCCTTTATCCCCTTCGATGT }\end{array}$ & $54^{\circ} \mathrm{C}$ & 699 & Kim et al. (2013). \\
\hline $\begin{array}{l}\text { groEL F-1 } \\
\text { groELR-1 }\end{array}$ & $\begin{array}{l}\text { AGCTATGATTCGTGAAGGT } \\
\text { AAGTAATAACGCCGTCGT }\end{array}$ & $54^{\circ} \mathrm{C}$ & 236 & Kim et al. (2013). \\
\hline
\end{tabular}

AT= Annealing Temperature.

\section{Amplified fragments visualization}

Agarose gel electrophoresis 1.5\% (wt/vol) was used for migrating the amplified DNA fragments. Gel was stained with ethidium bromide $(0.5 \mu \mathrm{L} / \mathrm{mL})$ and directly loaded on the gel, DNA ladder was also loaded on the gel for fragment size comparison and visualized under UV light using electrophoresis machine (Mupid-exU, Mupid, Tokyo, Japan). Also, the concentration of the extracted DNA was measured by using UV- spectrophotometer (Model UV-1700, Shimadzu, Tokyo, Japan).

\section{Tested Bacillus group strains}

Ten identified Bacillus cultures were used in the present study, six isolates belonging to Bacillus cereus, while the rest four cultures were belonging to Bacillus mycoides. However, all the tested cultures were isolated from different dairy products.

\section{DNA extraction from Bacillus group strains}

The DNA was extracted according to manufacture instructions by using DNA extraction kit (Wizard Genomic DNA purification kit, Promega, Madison, WI, USA).

\section{PCR amplification and PCR reaction condition}

The PCR amplification reactions were prepared in a total volume of $20 \mu \mathrm{L}$ contained $30 \mathrm{pM}$ of each primer, $20 \mathrm{ng}$ of DNA template, $10 \mathrm{mM}$ Tris- $\mathrm{HCl}, 1.5 \mathrm{mM} \mathrm{MgCl}$, 30 $\mathrm{mM} \mathrm{KCl}, 250 \mu \mathrm{M}$ dNTP mixture and $1 \mathrm{U}$ Top DNA polymerase (Bioneer, Daejeon, Korea).

\section{The PCR conditions were as follows}

Per-denaturation at $94{ }^{\circ} \mathrm{C}$ for $10 \mathrm{~min}$., followed by 35 cycles of $94^{\circ} \mathrm{C}$ for $1 \mathrm{~min}$., annealing temperature was tested at $54{ }^{\circ} \mathrm{C}$ and $72{ }^{\circ} \mathrm{C}$ for $1 \mathrm{~min}$. and a final elongation cycle at $72{ }^{\circ} \mathrm{C}$ for $5 \mathrm{~min}$. 


\section{RESULTS AND DISCUSSION}

Nowadays, molecular techniques have been increased and successfully applied to detect diarrheal and emetic toxins producing by Bacillus cereus group strains (Kim et al. 2013). Thus, polymerase chain reaction (PCR) assay using $B$. cereus group specific triple primer CER, CES and groEL primers was carried out.

In this respect, a total genomic DNA was extracted from the ten tested isolates by using Zymo Research Fungal / Bacterial DNA Prep $^{\mathrm{TM}}$ Kit. Also three species specific primer pairs were used. Results from Table 1 showed that after testing each of the three primer set, groEL-F-1 / groEL-R-1 was highly specific for detection of gene groEl.

Results of amplified PCR fragments for ten tested Bacillus strains are shown in Figure
1. It is very clear from the results obtained that product of Bacillus cereus Dc 8-1 which isolated from Domiati cheese scored $236 \mathrm{bp}$ in lan 1 by using primer pair (groEL F1/groEL R-1). In addition, strains Bacillus cereus Rc 5-1 and Rc6-1 that were isolated from Ras cheese yielded amplified fragment of $236 \mathrm{bp}$ in lan ( 3 and 4 ) by using primer (groEL F-1/groEL R-1).

Moreover, it is of interest to notice that both strains belonging to $B$. mycoides, named Rc 2-1 and Dc 7-1, isolated from Ras and Domiati cheese, respectively, showed amplified product of $236 \mathrm{bp}$ in lan (5 and 6) by using the same primer (groEL F-1/groEL $\mathrm{R}-1)$.

In contrast, none of rest tested strains either B. cereus or B. mycoides yielded any amplified product in this PCR reaction as shown in Figure 1 and Table 1.

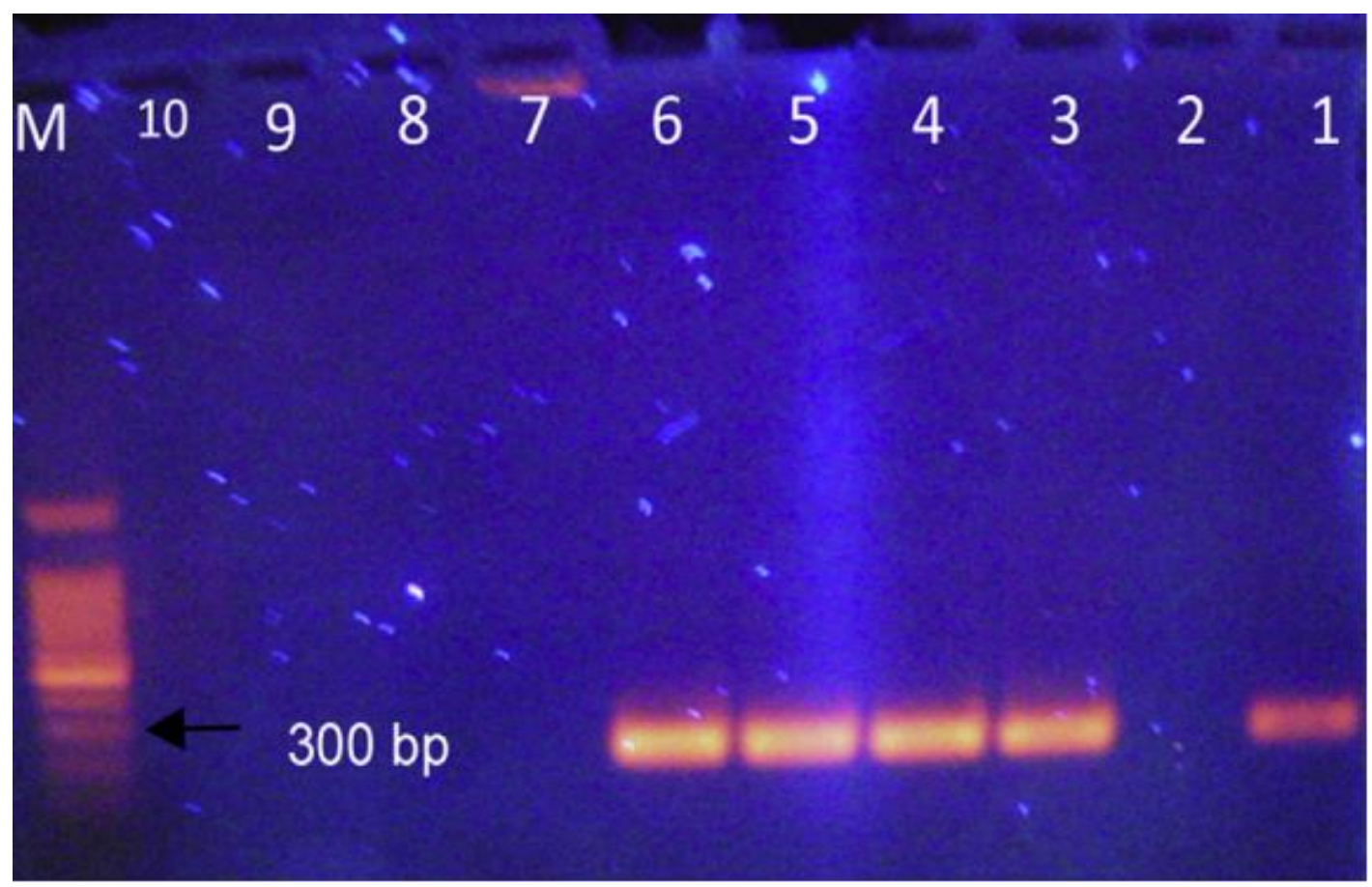

Figure 1. Gel electrophoresis of PCR products amplified with triple-primer on emetic and diarrheal toxin producing B. cereus and B. mycoides strains. M: DNA ladder $100 \mathrm{bp}$ from promega. Lane 1: $B$. cereus Dc8-1, Lane 2: B. mycoides Dc1-1, Lane 3: B. cereus Rc5-1, Lane 4: B. cereus Rc6-1, Lane 5: B. mycoides Rc2-1, Lane 6: B. mycoides Dc7-1, Lane 7: B. mycoides Rm5-2, Lane 8: B. cereus Rc5-2, Lane 9: B. cereus Dc10-1, Lane 10: B. cereus Dc10-2. 
Results of Table (2) showed that all the diarrheal enterotoxin producing $B$. cereus strains showed the presence of groEL gene but CER and CES genes were not present in any of the $B$. cereus strains tested in this study. Results also, clearly indicated that the $3 B$. cereus strains out of 6 strains from Domiati cheese (one strain), namely B. cereus Dc8-1 and Ras cheese (2 strains), namely B. cereus Rc5-1 and B. cereus Rc6-1 gave positive with groEL gene only and gave negative with CER and CES genes.

Table 2. PCR assays of emetic and diarrheal enterotoxins producing by B. cereus strains.

\begin{tabular}{|c|c|c|c|c|c|c|}
\hline \multirow[t]{2}{*}{ Strains } & \multirow[t]{2}{*}{ Sources } & \multicolumn{3}{|c|}{$\begin{array}{l}\text { Enterotoxin producing } \\
\text { B. cereus specific PCR primers }\end{array}$} & \multirow{2}{*}{$\begin{array}{c}\text { Emetic } \\
\text { toxin } \\
\text { producing }\end{array}$} & \multirow{2}{*}{$\begin{array}{l}\text { Diarrheal } \\
\text { toxin } \\
\text { producing }\end{array}$} \\
\hline & & CER & CES & groEL & & \\
\hline B. cereus Dc8-1 & Domiati cheese & - & - & + & - & + \\
\hline B. cereus Rc5-1 & Ras cheese & - & - & + & - & + \\
\hline B. cereus Rc6-1 & Ras cheese & - & - & + & - & + \\
\hline B. cereus Rc5-2 & Ras cheese & - & - & - & - & - \\
\hline B. cereus Dc10-1 & Domiati cheese & - & - & - & - & - \\
\hline B. cereus Dc10-2 & Domiati cheese & - & - & - & - & - \\
\hline \multicolumn{5}{|c|}{ No. of positive producing toxin strains } & 0 & 3 \\
\hline
\end{tabular}

It could be extracted from Table (3) that, all the diarrheal enterotoxin producing $B$. mycoides strains showed the presence of groEL gene but CER and CES genes were not present in any of the $B$. mycoides strains tested in this study. Results also, indicated that the 2 B. mycoides strains out of 4 strains from Ras cheese (one strain), namely B. mycoides Rc2-1 and Domiati cheese (one strain), namely $B$. mycoides Dc7-1 gave positive with groEL gene only and gave negative with CER and CES genes.

Table (4) also, shows that $50 \%$ of tested $B$. cereus strains from both Ras cheese and Domiati cheese samples were toxigenic and showed the presence of groEL gene but CER and CES genes were not present in any of the $B$. cereus strains tested. The same behavior was noticed with $50 \%$ of tested B. mycoides strains which showed the presence of groEL gene but CER and CES genes were not present in any of the B. mycoides strains tested CONCLUSION

The obtained results in this study revealed that the tested strains of $B$. cereus and B. mycoides showed the presence of groEL genes, while CER and CES genes were completely absent. B. cereus group had an ability to produce diarrheal enterotoxin, but the tested strains of all B. cereus and B. mycoides had a limited ability to produce emetic toxin.

Table 3. PCR assays of emetic and diarrheal enterotoxins producing by B. mycoides strains.

\begin{tabular}{|c|c|c|c|c|c|c|}
\hline \multirow[t]{2}{*}{ Strains } & \multirow[t]{2}{*}{ Sources } & \multicolumn{3}{|c|}{$\begin{array}{l}\text { Enterotoxin producing } B . \\
\text { mycoides specific PCR primers }\end{array}$} & \multirow{2}{*}{$\begin{array}{c}\text { Emetic } \\
\text { toxin } \\
\text { producing }\end{array}$} & \multirow{2}{*}{$\begin{array}{c}\text { Diarrheal } \\
\text { toxin } \\
\text { producing }\end{array}$} \\
\hline & & CER & CES & groEL & & \\
\hline B. mycoides Dc1-1 & $\begin{array}{l}\text { Domiati } \\
\text { cheese }\end{array}$ & - & - & - & - & - \\
\hline B. mycoides Rc2-1 & Ras cheese & - & - & + & - & + \\
\hline B. mycoides Dc7-1 & $\begin{array}{l}\text { Domiati } \\
\text { cheese }\end{array}$ & - & - & + & - & + \\
\hline B. mycoides Rm5-2 & Raw milk & - & - & - & - & - \\
\hline \multicolumn{5}{|c|}{ No. of positive producing toxin strains } & 0 & 2 \\
\hline
\end{tabular}


Table 4. Enterotoxin genes in B. cereus and B. mycoides strains.

\begin{tabular}{lccc}
\hline Primers & Genes & $\begin{array}{c}\text { Percentage positive } \\
\text { in B. cereus }(\mathrm{No}=6)\end{array}$ & $\begin{array}{c}\text { Percentage positive in } \\
\text { B. mycoides (No=4) }\end{array}$ \\
\hline $\begin{array}{l}\text { CER F-5 } \\
\text { CER R-5 }\end{array}$ & CER & 0 & 0 \\
\hline CES F-10 & CES & 0 & 0 \\
CES R-10 & & $50 \%$ & $50 \%$ \\
\hline groEL F-1 & groEL & 5 & \\
\hline
\end{tabular}

\section{REFERENCES}

Arnesen, L.P.S., Fagerlund, A., Granum, P.E., 2008. Bacillus cereus and its food poisoning toxins. FEMS Microbiol. Rev., 32, 579-606.

Bartoszewicz, M., Hansen, B.M., Swiecicka, I., 2008. The members of the Bacillus cereus group are commonly present contaminants of fresh and heat-treated milk. Food Microbiol., 25, 588-596.

Bennett, S.D., Walsh, K.A., Gould, H.A., 2013. Foodborne disease outbreaks caused by Bacillus cereus, Clostridium perfringens, and Staphylococcus aureus-United States, 19982008. Clin. Infect. Dis. 57, 425-33.

Bhunia, A.K., 2008. Bacillus cereus and Bacillus anthracis, In: Foodborne Microbial Pathogens. Springer, NY, pp- 135-148.

Dietrich, R., Moravek, M., Burk, C., Granum, P.E., Martlbauer, E., 2005. Production and characterization of antibodies against each of the three subunits of the Bacillus cereus nonhemolytic enterotoxin complex. Appl. Environ. Microbiol., 71, 8214-8220.

Duc, L.H., Ding, T.C., Logan, N.A., Sutherland, A.D., Taylor, J., Cutting, S.M., 2005. Cases of emesis associated with bacterial contamination of an infant breakfast cereal product. Int. J. Food Microbiol., 102, 245-251.

Ehling-Schulz, M., Vukov, N., Schulz, A., Shaheen, R., Andersson, M., 2005. Identification and partial characterization of the nonribosomal peptide synthetase gene responsible for cereulide production in emetic Bacillus cereus. Appl. Environ. Microbiol., 71, 105-113.
Fermanian, C., Lapeyre, C., Fremy, J.M., Claisse, M., 1997. Diarrhoeal toxin production at low temperatures by selected strains of Bacillus cereus. J. Dairy Res., 64 (4), 551-559.

Kim, G.H., Forghani, F., Oh, D.H., 2013. Rapid detection of emetic toxin producing Bacillus cereus strains using triple-primer polymerase chain reaction (PCR) assay. Afr. J. Microbiol. Res., 7 (8), 620-625.

Lund, T., De Buyser, M.L., Granum, P.E., 2000. A new cytotoxin from Bacillus cereus that may cause necrotic enteritis. Mol. Microbiol., 38, 254-261.

Mohamed, A.S., Alnakip, M.E.A., Abd-El Aal, S.E., 2016. Occurrence of Bacillus cereus in raw milk and some dairy products in Egypt. Japanese J. Vet. Res., 64, 95-102.

Reyes, J.E., Bastias, J.M., Gutierrez, M.R., Rodriguez, M.O., 2007. Prevalence of Bacillus cereus in dried milk products used by Chilean school feeding program. Food Microbiol., 24, 1-6.

Rodriguez-Lozano, A., Campagnoli, M., Jewel, K., Monadjemi, F., Gaze, J.E., 2010. Bacillus spp. thermal resistance and validation in soups. In: Mendez A., (Ed.). Current Research, Technology and Education Topics in Applied Microbiology and Microbial Biotechniligy, 537-544.

Sadek, Z.I., Fathi, F.A., Salem, M.M.E., 2006. Incidence, survival and biocontrol of psychrotrophic Bacillus cereus and its potential for toxin production in milk and tallaga cheese. J. Food Nutr. Sci., 15 (4), 419-425. 
Sergeev, N., Distler, M., Vargas, M., Chizhikov, V., Herold, K., Rasooly, A., 2005. Microarray analysis of Bacillus cereus group virulence factors. J. Microbiol. Methods, 65, 488-502.

Stenfors Arnesen, L.P., Fagerlund, A., Granum, P.E., 2008. From soil to gut: Bacillus cereus and its food poisoning toxins. FEMS Microbiol. Rev., 32, 579-606.
Tan, A., Heaton, S., Farr, L., Bates, J., 1997. The use of Bacillus diarrhoeal enterotoxin (BDE) detection using an ELISA technique in the confirmation of the aetiology of Bacillus-mediated diarrhoea. J. Appl. Microbiol., 82 (6), 677-682.

Zhou, G., Zheng, D., Dou, L., Cai, Q., Yuan, Z., 2010. Occurrence of psychrotolerant Bacillus cereus group strains in ice creams. Int. J. Food Microbiol., 137, 143-146. 


\section{استخدام تقنية الـ كCR كقارنة حديثة في الكشف عن التوكسينات \\ خاطر عبد الفناح أحمد خاطر "، شريف عادل سعد عبد اللا}

قسم الألبان، كلية الزراعة، جامعة الأزهر، القاهرة، مصر

khaterkhater.5@azhar.edu.eg البريد الإليكتروني للباحث الرئيسي: *

الملخص العربي

تعتبر بكتيريا بمموعة cereus أحد أهم المشكلات الواردة، لأهها يككن أن تلوث العديد من منتجات الألبان. في هذه الدراسة، تم اختيار ثلاثة أنواع من

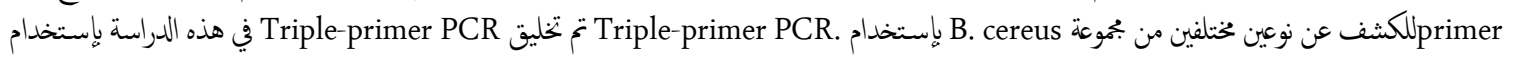

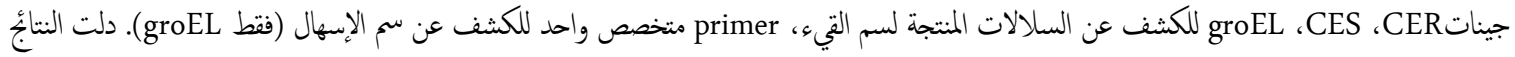

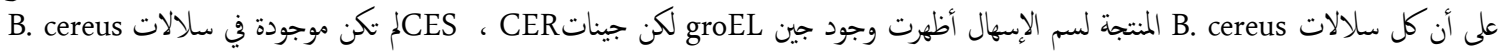

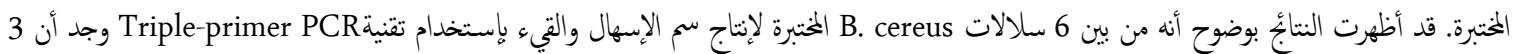

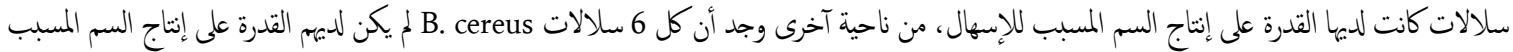

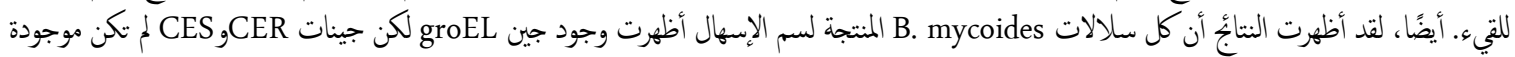

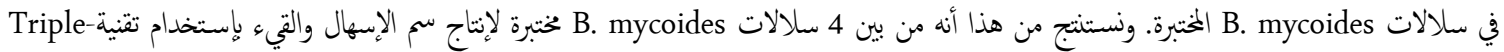

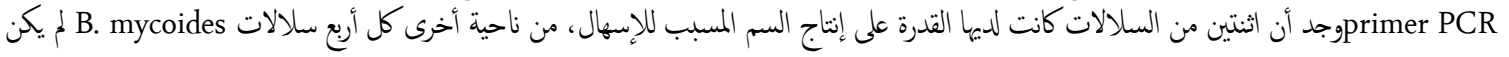

$$
\text { لديهم القدرة على إنتاج السم المسبب للقيى. }
$$

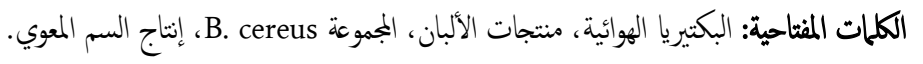

